\title{
Experimental trials on the feasibility of offshore seed production of the mussel Mytilus edulis in the German Bight: installation, technical requirements and environmental conditions
}

\author{
Bela Hieronymus Buck
}

Received: 17 July 2006 / Revised: 16 November 2006 / Accepted: 1 December 2006 / Published online: 20 January 2007

(C) Springer-Verlag and AWI 2007

\begin{abstract}
This study summarizes the activities and findings during a 2 year investigation on the grow-out of blue mussels (Mytilus edulis) and the technical requirements to withstand harsh weather conditions at an offshore location. The experimental sites were two different test areas, each 5 ha in size, $12-15 \mathrm{~m}$ in depth, in the vicinity of the offshore lighthouse "Roter Sand" located 15-17 nautical miles northwest of the city of Bremerhaven (Germany). Two versions of submerged longline systems were deployed: a conventional polypropylene longline in 2002 as well as a steel hawser longline in 2003, both featuring different versions of buoyancy modes. The spat collectors and grow-out ropes were suspended perpendicular from the horizontal longline for several months beginning in March of each respective year. The test sites were visited and sampled on a monthly basis using research vessels. Larval abundances in the surrounding water column reached numbers of up to 1,467 individuals $\mathrm{m}^{-3}$. Postlarval settlement success varied through the entire experimental period, ranging from 29 to 796 individuals of spat per meter of collector. Settled mussels reached a shell length of up to $28 \mathrm{~mm} 6$ months after settlement. Based on the growth rates observed for the seed, it is projected that mussels would reach market size $(50 \mathrm{~mm})$ in $12-15$ months post settlement, and at the observed densities, each meter of collector rope could
\end{abstract}

Communicated by F. Buchholz.

B. H. Buck $(\square)$

Alfred Wegener Institute for Polar

and Marine Research (AWI),

Am Handelshafen 12,

27570 Bremerhaven, Germany

e-mail: Bela.H.Buck@awi.de yield $10.9 \mathrm{~kg}$ of harvestable mussels. The polypropylene line resisted storm conditions with wind waves of up to $6.4 \mathrm{~m}$ and current velocities of $1.52 \mathrm{~m} \mathrm{~s}^{-1}$ and was retrieved in autumn of 2002. In contrast, the steel hawser-based line did not withstand the harsh weather conditions. The steel-based line consisted of six twisted strands that were untwisted by the strong currents and turbulences and consequently the individual strands were torn. Additionally, the line was accidentally cut by a yacht in July 2003 . The biological study revealed that the tested location near "Roter Sand" has the potential to become an offshore seed production site as well as being exploitable as a grow-out site for mussel production to market size. In light of the technical results, recommendations for mussel culture strategies using a polypropylene longline system are given.

Keywords Mussel farming - Submerged longline · Culture design $\cdot$ Offshore aquaculture $\cdot$ Larvae distribution $\cdot$ Settlement

\section{Introduction}

Presently, a number of species of mussels are farmed globally, the most common of which is the blue mussel (FAO 2004). Following the data recorded by the FAO, China is now the largest producer of blue mussels where its culture technique depends on a high proportion of spat being produced from hatcheries. Other important producers of blue mussels are Spain, the Netherlands, France, and the UK followed by Ireland and Germany (FAO 2004).

In Europe, blue mussel farming started early in the past century and was based mainly on the raft method. 
Other off-bottom culture techniques are pole (France), rack (also France and Tahiti) and longline (e.g., Ireland, Norway, New Zealand, China) systems (Hickman 1992). In Germany, the Netherlands and Denmark, mussels are cultivated using the on-bottom culture method (Seaman and Ruth 1997). Mussels are collected from natural beds and transferred to licensed culture plots, where environmental conditions are suitable for growth and fattening. However, the intertidal and subtidal bottom culture plots are subject to predation pressure, such as ducks [e.g., Somateria mollissima (Hamilton 1997, Hamilton et al. 1999)], starfish [e.g., Asterias rubens (Kristensen and Lassen 1997; Reusch and Chapman 1997; Dolmer 1998)] or crabs [e.g., Carcinus spp. (Leonard et al. 1999)]. Furthermore, this technique depends on the availability of seed mussels obtained from wild habitats in the Wadden Sea (Seaman and Ruth 1997). Additionally, due to the nature reserve status of almost $98 \%$ of the German North Sea coast, the development and scale-up of the mussel aquaculture sector is limited. Culture plot sizes are decreasing in order to follow the mussel management plans of Schleswig-Holstein and Lower-Saxony (e.g., CWSS 2002; Buck 2002) with no new licenses being approved in the future.

In most places in Europe the development of mussel culture has taken place almost exclusively in protected nearshore waters and estuarine habitats. In Germany, sheltered locations are rare and because of stakeholder conflicts the development of coastal aquaculture is rather stagnant. However, it is widely believed that the commercialization of ocean mariculture in more exposed locations, in the open ocean, has tremendous future economic potential (Buck 2002; Ewaldsen 2003). In 1998, the University of New Hampshire initiated the Open Ocean Aquaculture Demonstration Project to investigate the commercial potential of environmental responsible seafood production, employment opportunities, engineering solutions and operational methodologies of offshore aquaculture (Bucklin and Howell 1998). As part of the project Langan and Horton (2003) deployed two $120 \mathrm{~m}$ submerged longlines for shellfish culture $10 \mathrm{~km}$ off the coast of Portsmouth (New Hampshire) in the southwestern Gulf of Maine, where the biological and commercial feasibility of Mytilus edulis cultivation was tested.

In the German North Sea, offshore cultivation of some candidates, such as the two seaweed species of Laminaria digitata and L. saccharina, showed promising results (Buck and Buchholz 2004, 2005). However, no attempts to use the open ocean in the North Sea for mussel aquaculture were established yet. Since 2000 a new industry enters the scene: the offshore wind farm operators in the German Bight. These new stakeholders are seen as a chance to combine renewable energy production with cultivation of organisms, thereby the idea for synergistic resource uses in form of offshore aquaculture was born. While the offshore wind farm areas are closed for commercial shipping and fishery, aquaculture constructions can be installed within these wind farms utilizing the same protective benefits (Krause et al. 2003). Additionally, the wind generators themselves represent infrastructure to which aquaculture constructions can be linked (Buck et al. 2004, 2006).

Offshore sites in the North Sea are exposed to high waves and strong currents, requiring engineering structures that can survive the largest wave formations at a site while at the same time supporting the growth of the cultured organisms, preventing detachment and subsequent loss. Numerous environmental conditions are important to the success of an offshore mussel aquaculture operation, such as phytoplankton biomass represented by chlorophyll content and the $\mathrm{C} / \mathrm{N}$-ratio, to obtain good growth rates, physico-chemical parameters within optimum range to prevent losses due to mortality, predation, and a reliable seasonal occurrence of abundant natural larvae and juvenile spat fall for settlement on collectors. Until today, there are no data available on an overall offshore design of constructions for mussel longline cultivation in the North Sea. In this case, the term "offshore" will be defined (1) being in an area fully exposed to all kinds of environmental conditions (Ryan 2005) and because of tremendous stakeholder conflicts (Dahle et al. 1991) in coastal areas (2) being at least eight nautical miles off the coast (Buck 2004).

This is the first study in European territorial waters where a new longline-design was installed to resist an extremely high-energy environment, to test system strength and to focus on site selection criteria. Further, the biological and technical feasibility of mussel spat collection at an offshore location adjacent to a planned offshore wind farm was investigated. To follow some important biological aspects in this study several parameters were routinely measured, such as the concentration of mussel larvae in the water column and the settlement success. Furthermore, a biological supporting programme was carried out to determine local conditions, such as chlorophyll concentrations and $\mathrm{C} / \mathrm{N}$ ratio to indicate food availability and quality, temperature and salinity to indicate conditions within the water body as well as some oceanographic data, such as current velocity and wave height to test system strength. The technical feasibility was tested by employing two promising versions of longline constructions. The techniques were designed to withstand harsh conditions 
while also supporting suitable operational requirements such as maintenance and retrieval techniques for mussels grown to market size. In addition, the system should be commercially feasible and operate a durable longline and mooring system.

\section{Materials and methods}

Location of the study sites and local environmental conditions

Two study sites (12-15 $\mathrm{m}$ in depth) were established in the vicinity of the offshore lighthouse "Roter Sand", which is located 17 nautical miles NW of the city of Bremerhaven (Germany). This marine area, commonly called "Nordergründe", was chosen because of the adjacent offshore wind farm, planned from the company "Energiekontor" (Fig. 1). Because of an option contract between the wind farm operator and the responsible Water and Shipping Agency (WSA) a permit at the same site could not be obtained. An approval in the vicinity of the planned wind farm site for the utilisation of the study sites was obtained in January 2002.

The wave climate, the current velocities and direction at the study sites were under continuous observation of the Federal Maritime and Hydrographic Agency (BSH) and the local Water and Shipping Agency (WSA), which deployed a wave-following buoy (Waverider, Datawell) and an acoustic doppler current meter (RCM 9, Aanderaa) and shared the data sets obtained during the study period.

Design and construction of the longline and mooring system

Longline shellfish culture involves a system of horizontal ropes anchored to the seafloor with buoys to provide flotation, to which vertical droppers are attached. The specific design of the system dimensions depends on site conditions. Here, longlines were used for both; spat collection as well as for the grow-out of juvenile mussels. Two different anchored longlines (Fig. 2) were installed in order to test their suitability under open sea conditions in terms of material and functionality: (1) a polypropylene-based design in 2002 and (2) a steel hawser-based design in 2003. In a first test the longline systems and their mooring devices were modelled and designed. A local cable and wire manufacturer supported the engineering development for the culture design. All components were selected and procured to start the preparation and assemblage of the longline during wintertime.
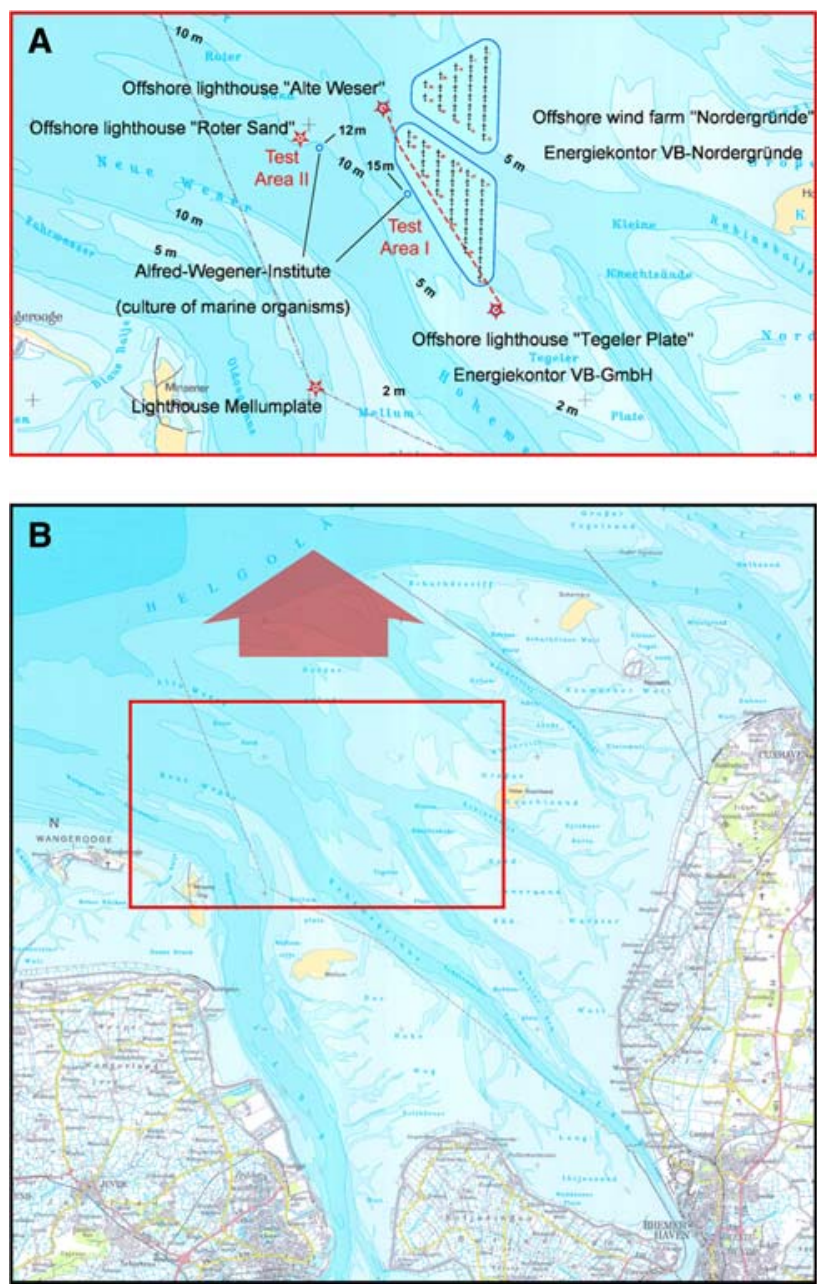

Fig. 1 Map of the southern German Bight. The enlarged upper inset illustrates the test area No. I, "Nordergründe", and the test area No. II at the offshore lighthouse "Roter Sand". The wind mills indicate the planned offshore wind farm "Energiekontor"

Both culture systems were based on the same fundamental setup (Fig. 2). The longline operated in a submerged mode at a depth of about $5 \mathrm{~m}$ horizontally below the surface to avoid the destructive effects of surface waves. The longline had at both sides a $10 \mathrm{~m}$ "undisturbed end", which could not be retrieved when sampling or harvesting. Buoys were fixed along the longline in combination with suspended mussel spat collectors. The three-stranded collectors (Galician type, $2.5 \mathrm{~m}$ long, Fig. 3a, b), equipped with horizontal inserted pegs to prevent attached mussels to be shaken off through current and wave forces, were suspended every $2 \mathrm{~m}$ perpendicular from the longline in a parallel manner. Each collector had a weight of approximately $3 \mathrm{~kg}$ at the bottom end and was on the top end hooked into the longline by shackles. Tufts of unravelled polypropylene lines (Tortell 1976) were also connected to the longline (Fig. 3c) to determine the settlement of 
Fig. 2 Submerged longline system designs with spat collector harness a polypropylene-based longline above (longline I) and $\mathbf{b}$ a steel hawser-based longline. The insets show the coupling elements and $\mathbf{d}, \mathbf{e}$ the connection of floats and collectors. c Polypropylene and steel hawser, d, e steel hawser

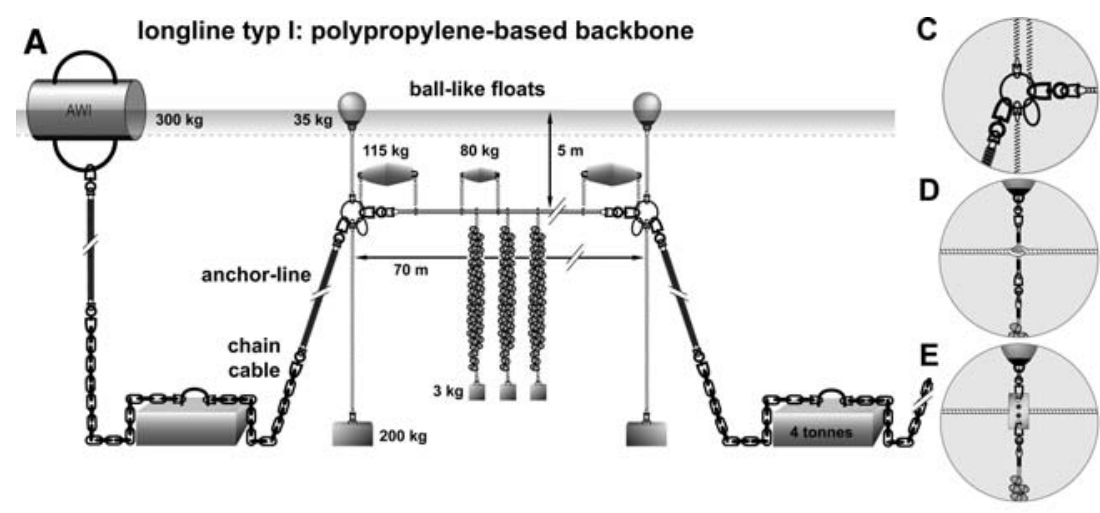

B

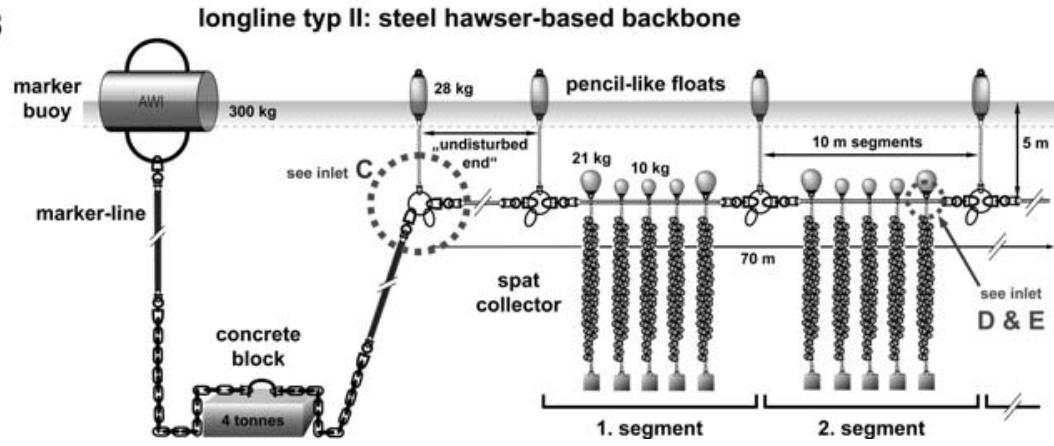

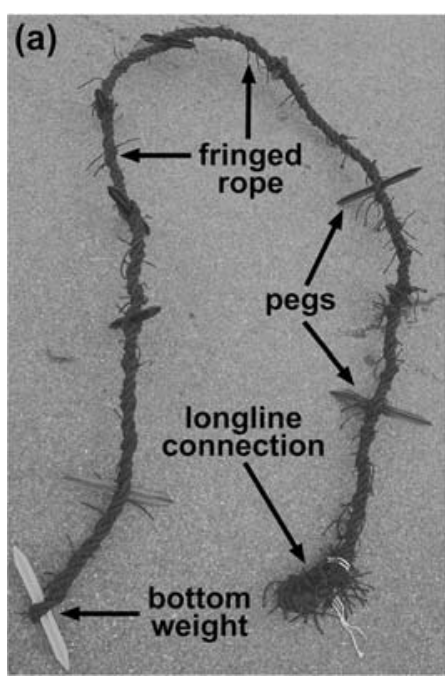
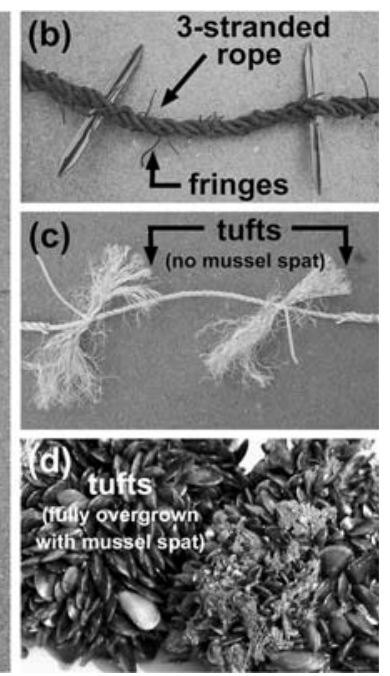

Fig. 3 Collector and tuft design for the settlement of Mytilus larvae. a Shows a collector rope (Galician type) for the settlement and grow out of blue mussels, $\mathbf{b}$ shows an enlargement of the collector rope to display attached fringes which ease larval settlement, c presents a tuft for larval settlement and $\mathbf{d}$ demonstrates a tuft fully overgrown by juvenile blue mussels

mussel post-larvae (Fig. 3d). The longline was secured at each end with an anchor consisting of a $4 t$ concrete block. A chain cable attached to the concrete block was connected to the anchor-line, which itself holds one end of the longline. Additionally, each concrete block was equipped with a marker-line and a marker buoy $(300 \mathrm{~kg})$. The marker line had a service load of several tonnes that it could be used to tauten the longline and to retrieve the concrete block at the end of the project. All mooring components were selected and sized for the use in muddy sea bottom and for longterm durability. All longline segments had spliced eye loops with embedded galvanized thimbles at the ends and at all coupling elements shackles and swivels were used (Fig. 2c).

The 3-stranded polypropylene-based longline $(\varnothing=$ $32 \mathrm{~mm}$ ) was made of two $35 \mathrm{~m}$ long segmental parts connected to each other. To keep the longline afloat each segment was equipped with one $80 \mathrm{~kg}$ buoyancy barrel in the centre and with $115 \mathrm{~kg}$ barrels at the coupling to the anchor-line. Further, a few $35 \mathrm{~kg}$ ball-like surface marker floats were fixed to a $5 \mathrm{~m}$ rope, which was connected to the longline. Three steel barrels filled with concrete $(200 \mathrm{~kg})$ tightened the longline to the sea bottom at the coupling to the anchor-line and in the centre.

The 3-stranded steel hawser-based longline $(\varnothing=20$ $\mathrm{mm}$ ) had a similar set up as it was described for the polypropylene line, however, the longline consisted of more sections: seven $10 \mathrm{~m}$ long segments with each three $10 \mathrm{~kg}$ submersed floats in the centre and at each coupling elements $21 \mathrm{~kg}$ submersed floats. All floats were connected to a short wire element, which itself was spliced perpendicularly into the hawser and squeezed by one of the hawser's strands (Fig. 2d). An alternative attachment was the use of flat steel panels 
tightly fixed to the longline to which both, the floats and the collectors, were attached (Fig. 2e). Due to the weight of the steel wire the longline had more floaters than the polypropylene-based longline and no additional weights were attached to the longline. At all coupling elements pencil-like fenders $(28 \mathrm{~kg})$ were attached to mark the longline at the surface.

Deployment of the entire longline system and maintenance

The Water and Shipping Agency (WSA; Bremerhaven) provided assistance to deploy the moorings and to install the entire longline by using the buoy tender Bruno Illing. Both longlines were deployed in March, the polypropylene-based line in test area I (2002) and the steel hawser-based longline in test area II (2003) (Fig. 1). Marker buoys were deployed to establish the corners of both chartered test areas in order to mark and protect the site for navigation purposes. In test area II marker buoys were lighted. In the area of Nordergründe the main current direction is bidirectional from NW to SE and vice versa depending on tides. To avoid high drag forces on the longline we decided to deploy the entire longline parallel to the flow.

The polypropylene longlines were installed when the concrete blocks with the chain cable and the anchor-line had already been deployed at sea. The anchor-line had already been connected to the 1151 barrel to keep it afloat. Afterwards, each part of the two $35 \mathrm{~m}$ longlines, which were fully equipped with collectors and floats, were deployed at sea and connected to the anchor-lines and to each other in the centre.

The steel hawser-based longline was fully equipped with floats and collectors ahead of time and prepared on board of the servicing vessel Bruno Illing. One end of the longline had already been fixed to the chain cable of one mooring. While lowering the first concrete block to the sea bottom the longline was carefully paid out until the second concrete block was deployed. Later, the longline was tightened by pulling the second concrete block with the marker-line until all longlinefloats were submersed.

From March to November 2002 and March to July 2003, monthly cruises were made to the study site for servicing purposes and data collection. Upon inspection and at harvest time the upper portion of the longline was raised to sea level. Fouling (except mussels) on the collector ropes and other deployed parts of the longline was not removed in order to follow how fouling develops and to determine how increasing weight impacts the total load on the longline. As the grow-out of mussels increases the suspended weight buoyancy was calculated and flotation was added do prevent the longline from sagging.

\section{Biological supporting programme}

Post-larval settlement was observed by individually retrieving collectors and tufts to take mussel samples. In the lab, numbers of settled post-larvae of Mytilus edulis were counted and measured in size under a stereomicroscope and transformed into mussel abundance per $\mathrm{cm}$ of rope.

Temperature and salinity profiles were taken using a CTD sensor (OTS 124, ME Kiel). Data describing chlorophyll contents and nutrient concentrations (nitrite, nitrate, ammonium, phosphate) of the surrounding water column were used from data provided by the BSH (2002/ 2003), the NLÖ (2003) and using the findings of Buck and Buchholz (2004). The nutrient concentrations were additionally used to describe the local conditions for phytoplankton growth in terms of site selection criteria.

On each cruise, seawater samples (three replicates) were taken in a depth of $2-5 \mathrm{~m}$ to determine $\mathrm{C} / \mathrm{N}$-ratio and larval concentrations. About 51 of seawater were pumped for particulate organic carbon (POC) and particulate organic nitrogen (PON) analysis and were stored deep frozen and analyzed in the laboratory. $\mathrm{C} / \mathrm{N}$ analysis was modified after the methodology described by von Bodungen et al. (1991). Samples were filtered over precombusted $\left(450^{\circ} \mathrm{C}\right.$, overnight $)$ glass fibre filters (Whatman $\mathrm{GF} / \mathrm{C}^{\circledR}$ ), washed with $2 \mathrm{ml}$ distilled water and dried at $65^{\circ} \mathrm{C}$. After weight determination the samples were acidified with $1 \mathrm{M} \mathrm{HCl}$ to remove inorganic carbonates and redried. $\mathrm{C} / \mathrm{N}$ was then determined by high temperature combustion (Nitrogen Analyser 1500, Carlo Erba Strumentazione). Acetanilide was used as calibration standard. To assess the abundance of mussel larvae prior to settlement, 501 of seawater were pumped from $5 \mathrm{~m}$ below water surface. Water samples were then filtered through metal plankton net (mesh size: $125 \mu \mathrm{m}$ ) and fixed in buffered formaldehyde $(4 \%)$ for later analysis. In the laboratory, larval samples were transferred to a grid chamber and larval concentration counted using a stereomicroscope.

\section{Statistical analysis of data}

Means and standard deviations (mean $\pm \mathrm{SD}$ ) of data on current velocities, wave heights, salinity, particulate organic carbon, particulate organic nitrogen, chlorophyll, larvae numbers, shell length and settlement success were calculated and some are presented in graphs as appropriate using Microsoft Office Excel 2003 software; these are shown in bars. 


\section{Results}

\section{Environmental conditions}

Current velocities measured at "Nordergründe" ranged from 0 to $1.52 \mathrm{~m} \mathrm{~s}^{-1}(n=5,188)$ showing a pronounced diurnal tidal variation (Fig. 4a). The current direction showed a bidirectional flow from $\mathrm{NW}$ to $\mathrm{SE}$ and vice versa $\left(314^{\circ} \leftrightarrow 114^{\circ}, y=-1.0497 \mathrm{x}\right.$ +4.5078 ) (Fig. 4b). The mean significant wave height during a 280 day measurement campaign in 2002 was recorded at $1.49 \mathrm{~m} \pm 1.01(n=2,259)$ with a maximum wave height of about $6.46 \mathrm{~m}$ (Fig. 4c). Temperature data varied throughout the year from 1.8 to $22.4^{\circ} \mathrm{C}$ as well as through tidal effects by $2.4^{\circ} \mathrm{C}$
(Fig. 4d; Table 1). Likewise, salinity was affected by the tidal regime and ranged from 26.7 to $31.1 \mathrm{ppt}$ (Fig. 4d).

Particulate organic carbon concentrations ranged from $198.53 \pm 17.6 \mu \mathrm{g} \mathrm{l}^{-1}$ (July) to $515.58 \pm 176.5 \mu \mathrm{g} \mathrm{l} \mathrm{l}^{-1}$ (January/February) and $549.85 \pm 385.8 \mu \mathrm{g} \mathrm{l}^{-1}$ (April). Particulate organic nitrogen ranged from $31.86 \pm$ $2.6 \mu \mathrm{g} \mathrm{l}^{-1}$ (July) to $66.69 \pm 21.6 \mu \mathrm{g} \mathrm{l}^{-1}$ (January/February) and $84.1 \pm 48.7 \mu \mathrm{g} \mathrm{l}^{-1}$ (April) (Table 1), respectively. This resulted in a $\mathrm{POC} / \mathrm{PON}(\mathrm{C} / \mathrm{N})$ ratio ranging from 6.2 to 7.7 throughout both years. Highest concentrations occurred in spring/early summer, reflecting the spring phytoplankton bloom, which is typical in this area (Walter et al. 2006). Total chlorophyll concentrations varied throughout the entire project period being
Fig. 4 Environmental conditions near the test location "Nordergründe" over a duration of 18 days in April (a, b and d) and 280 days c. a Shows the local current velocity influences by the tide, $\mathbf{b}$ shows the current velocity as a function of direction and tide, $\mathbf{c}$ demonstrates wave height and d displays the temperature and salinity regime influenced by the tides

Fig. 5 Annual chlorophyll ( $a, b, c_{1-2}$ and phaeophytin) characteristics at the test site (Nordergründe)
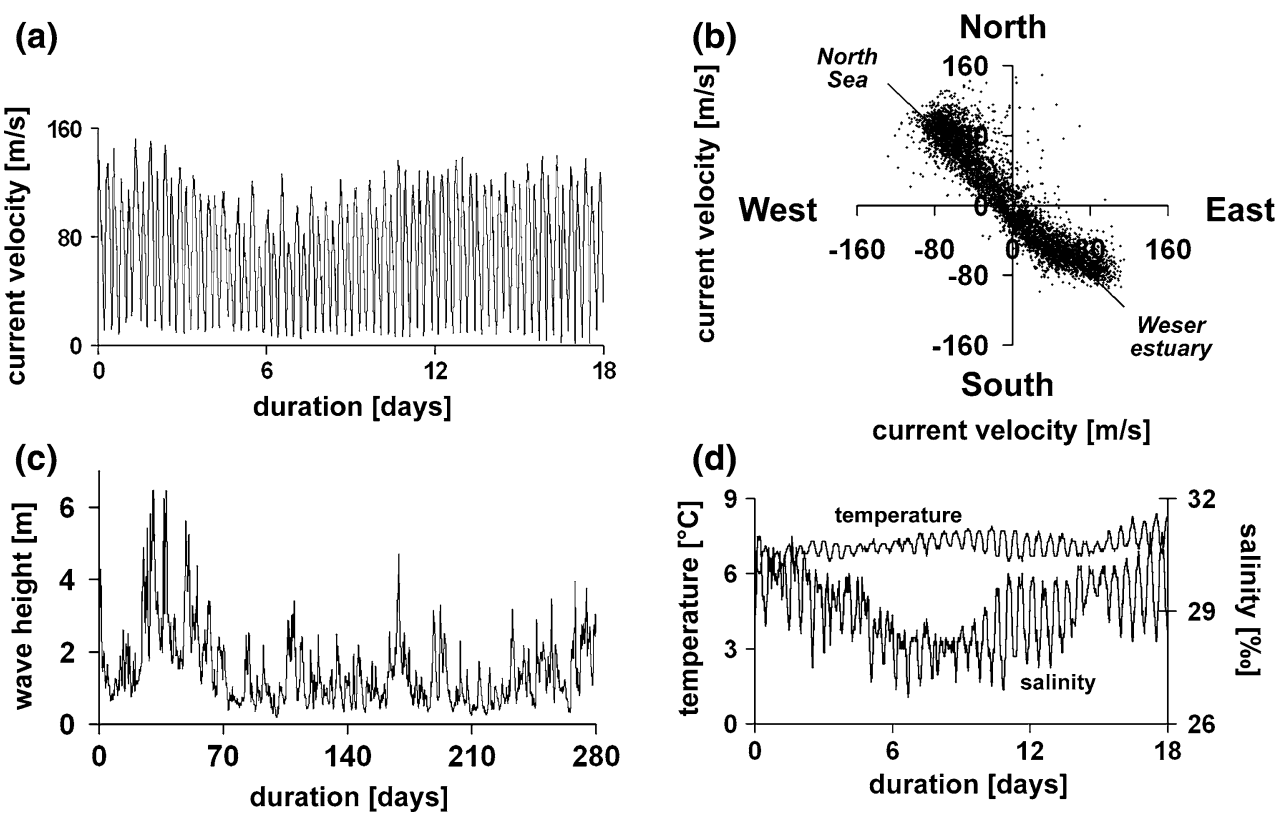

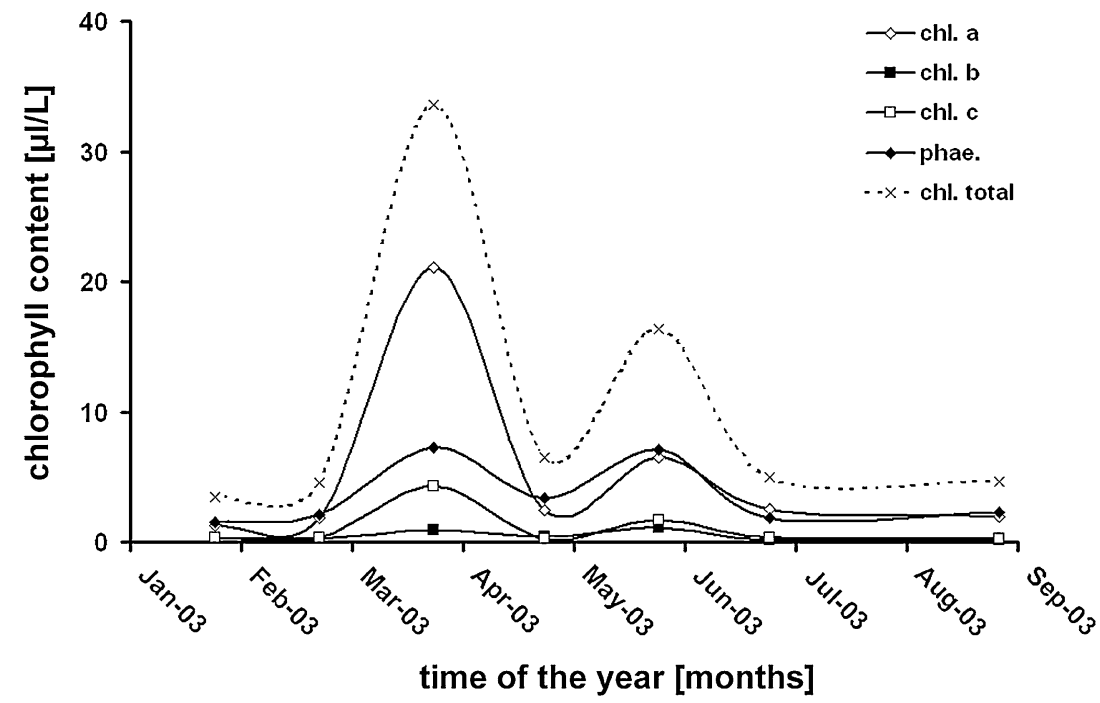


Table 1 Data of environmental conditions at the offshore test locations in 2002

\begin{tabular}{llllllll}
\hline Months & \multicolumn{2}{l}{ Nutrients $(\mu \mathrm{mol} / \mathrm{l})$} & \multicolumn{2}{l}{$\begin{array}{l}\text { Temperature } \\
\left({ }^{\circ} \mathrm{C}\right)\end{array}$} & POC $(\mu \mathrm{g} / \mathrm{l})$ & PON $(\mu \mathrm{g} / \mathrm{l})$ & $\mathrm{Chl}(\mu \mathrm{g} / \mathrm{l})$ \\
\cline { 2 - 5 } & Ammonium & Nitrate & Phosphate & & \\
\hline December-February & $0.3-4.4$ & $1.1-13.4$ & $0.1-0.4$ & $1.8-5.0$ & $35.2-84.3$ & $543.3-669.7$ & $3.3-3.7$ \\
March-May & $1.8-5.9$ & $6.1-55.4$ & $0.2-0.9$ & $6.1-11.3$ & $48.2-84.1$ & $335.7-549.8$ & $4.5-33.6$ \\
June-August & $0.9-6.5$ & $0.2-49.3$ & $1.3-1.7$ & $14.1-18.8$ & $29.4-34.3$ & $174.7-217.1$ & $4.9-16.4$ \\
September-November & $0.3-6.6$ & $0.9-10.2$ & $0.1-0.5$ & $18.2-2.1$ & $50.1-65.4$ & $327.1-450.6$ & $3.9-5.3$ \\
\hline
\end{tabular}

lowest in January/February $3.45 \pm 0.18 \mu \mathrm{g}^{-1}$ and September $4.63 \pm 0.65 \mu \mathrm{g} \mathrm{l}^{-1}$ and highest in April 33.61 $\pm 1.56 \mu \mathrm{g} \mathrm{l}^{-1}$ (Table 1, Fig. 5).

Concentrations of nutrients (ammonium, nitrate, and phosphate) analysed by the BSH and the NLÖ and according to Buck and Buchholz (2004) varied over an annual cycle as shown in Table 1. From these data it can be concluded that nitrogen and phosphate concentrations in the surrounding water were not limiting at any time of the test period, thus providing sufficient nutrients to allow phytoplankton growth.

\section{Larval concentration and spat settlement}

In April 2003, $25 \pm 5$ mussel larvae per $\mathrm{m}^{3}$ (ind. $\mathrm{m}^{-3}$, $n=3$ ) were recorded in the water column at "Nordergründe". Highest larval densities were determined in May with $1,467 \pm 455$ ind. $\mathrm{m}^{-3}(n=3)$, while a following gradual decrease in larval abundance attained $267 \pm 110$ ind. $\mathrm{m}^{-3}(n=3)$ in early September.

Wild mussel spat was found to settle abundantly in dense colonies on collector ropes, which appeared to compete successfully for space and food against fouling organisms over time. At the end of July, significant mussel growth was observed during site visits, but these mussels were too small for consumption.

During the last site visit in September 2002, the crew on board the RV Uthörn stripped a vast quantity of mussels from several collectors. Upon rising of the submerged longline to a position above sea level alongside of the RV Uthörn in September 2002 an amazingly large growth of self-seeded mussels was discovered. The $32 \mathrm{~mm}$ diameter longline had grown to up to 15$20 \mathrm{~cm}$ in diameter with marine growth during its 6 months submerged exposure at the offshore farm site "Nordergründe". Growth patterns along the line varied in mussel density, but the frequently large accumulations of mussels were always associated with abundant colonies of fouling organisms. The density of mussels on the grow-out lines ranged between $55 \pm 17$ (March) and $700 \pm 197$ (May) ind. $\mathrm{m}^{-1}$ line length during the first year of spat collection (mean $397 \pm 374$ ind. $\mathrm{m}^{-1}$ ) and ranged between $29 \pm 20$ (July) and $796 \pm 400$ (May) ind. $\mathrm{m}^{-1}$ in the second year. That yielded to an average of nearly $10.9 \mathrm{~kg}$ of mussels per meter collector rope. Mussel spat was $28 \pm 9.2 \mathrm{~mm}$ in size within 6 months of growth. These results indicate that a single longline of a dimension similar to that used for this project can yield up to 700$1,000 \mathrm{~kg}$ of mussel seed in a 6 months grow-out period and would last $12-15$ months to bring those mussels to market size.

\section{Longline design}

Problems encountered during the project include material failure; heavy fouling on the collector lines and other infrastructural units resulting in large ballast weights, while heavy predation on mussel seed by sea stars was also encountered. Another difficulty was maintaining proper headline depth as the mussels grow and add weight to the line.

On the engineering side the field experience with the deployment and servicing of units has been invaluable. Specific assets and drawbacks in both longline constructions were found, and this holds true for both, the polypropylene-based longline as well as the steelhawser-based longline. Most problems emerged by lifting of the longlines manually as well as by the cranes of the vessels. While all segments from the steel wire line had steel rings (mostly chain links) at all coupling elements to ease the hook up of the line, the saving of the polypropylene line often failed. The segmentation also allows the replacement of spare parts. Unfortunately, the transverse wires, which hold the floaters above and the collectors below, were quickly weakened and frequently broke because they were permanently being bended through the tidal currents. These stress forces affect the lifetime greatly. The polypropylene line was resistant to the highenergy environment of the North Sea, but chafed within the inner parts of the eye loops and therefore some of the thimbles were lost.

The weight of the suspended collector harness increased significantly with time, and extra floatation had to be added to support the buoyancy of the longline. However, the time intervals chosen for service were too long (particularly during the summer growing 
season) so that parts of the collector harness including the floats submersed fully and touched the seafloor. Additionally (in both constructions) loss of buoyancy resulted in a lowering of the total construction.

There is another lesson to be learned. Despite operating in an officially closed area encounters with sea traffic is not out of option. Unfortunately, a private yacht ignored the navigation marks and entered the test area in July 2003. With the attempt to cross the test area, the boat got entangled in the longline and some of the buoyancy ropes, which resulted in clipping the longline. An immediate retrieval of the entire longline to save samples and parts of the construction was not possible due to harsh weather conditions. Some days later only a fully destroyed longline could be heaved from the sea bottom. Due to the tidal currents the collector harness touched the sea bottom and chafed over the sediment, which resulted in the loss of all settled mussels.

When the longline was retrieved the concrete blocks were broken easily out of the clay at the site and raised by the anchor chain. On all mooring components heavy mussel growth was found. More mussels were recorded on the undisturbed ends of the longline at each side.

Most of the mooring system, in particular the longline and its harness, was later inspected onshore. On a few spots near the eye loops some slight damage of the material was found, but most of the line, after removing the fouling, looked intact and almost new.

\section{Discussion}

Mussel larvae numbers and post-larval settlement

At "Nordergründe" the cultivation of blue mussels can only be successful following a regular and reliable supply of Mytilus larvae originating from local spat fall. These two characteristics are the basis of every mussel culture enterprise and have been investigated even in countries, where mussel farming today is not yet established (Menzel 1991). In terms of mussel farming in Germany, mussel settlement has been found to be quite variable from year to year and from site to site (e.g., Walter and Liebezeit 2001; Ewaldsen 2003). Generally, however, late spring and early summer (Pulfrich 1997) is deemed to be the best time to collect spat on the pegged downropes used for on-growing (Walter and Liebezeit 2001). In addition, these scientists found out that even in years with a low spat fall determined on bottom culture plots mussel larvae are in vast quantities in the water column and are able to settle on suspended substrates.
Due to the anti-clockwise tidal currents in the North Sea (Becker et al. 1992; Ducrotoy et al. 2000) the settled post-larvae may originate from inshore mussel beds along the Lower-Saxonian coast and, in some cases, from the intertidal areas from the Dutch Wadden Sea. Data of larvae numbers determined in the water are equivalent to those reported by Dobretsov and Miron (2001) for the White Sea and CáceresMartínez and Figueras (1998) for NW Spain being $\approx 1.3$ and $1.2 \times 10^{3} \mathrm{~m}^{-3}$, respectively. Due to a dilution effect long drifts to offshore sites result in declining densities of mussel larvae in the water column (Young et al. 1998; Metaxas 2001; Buck 2004; Bos et al. 2006). While nearshore distribution and larval numbers within the water column are well known in the North Sea (e.g., Walter and Liebezeit 2001), only a few data are as yet available in offshore areas and are fragmentary (Buck 2004; Walter et al. 2006). However, if suitable substrates are available pediveligers settle and grow, while recruitment success and growth rates depend on environmental conditions.

The larval peak at "Nordergründe" timely coincides with highest larval concentrations found by Heiber (1988), Pulfrich (1995, 1997), de Vooys (1999), and Walter and Liebezeit (2001). However, the peak varies within the White Sea, NW Spain and the test location. While in the White Sea larval concentrations are highest in early August and in Spain between March and April the findings in this study show the most larval numbers in May. The reason for the differing regional spat falls may result from the water temperature reaching $12-14^{\circ} \mathrm{C}$ in March/April in Spain and at the same level first in May at "Nordergründe". In the White Sea, $12^{\circ} \mathrm{C}$ is first reached in August, which explains the late spat fall in Russia. The temperature peaks and the therefore resulting high concentration of Mytilus larvae are due to latitudinally differences. In southern regions the reproductive cycle starts earlier in the year due to increasing water temperature than conspecifics further north (Gabbott 1975). That explains the late spat fall in Norway in July-September (Lande 1973).

It is also reported that food supply determines the reproductive cycle of Mytilus edulis (Kautsky 1982; Seed and Suchanek 1992). As a value to measure food supply the concentration of chlorophyll in the water column as well as the POC/PON ratio was used. Here, the findings support this suggestion showing chlorophyll concentrations being highest in April/May and POC/PON ratios being around 6.8 and reflecting a "healthy planktonic organism community" (Kraul 1994). Additionally, nutrients were at no time a limiting factor to sustain microalgal growth. 
Settlement of mussel spat on tufts reached $\approx 700$ 800 ind. $\mathrm{m}^{-1}$ of the Galician type collector rope. Unfortunately, there are no data from offshore sites to compare these data with. Results from inshore sites at the Jade estuary at the German coast were determined by Walter and Liebezeit (2001) ranging between 10,000 and 70,000 ind. $\mathrm{m}^{-1}$ rope. This location has numerous natural mussel beds and culture plots in its vicinity, which explains the vast quantity of mussel spat per meter of rope. Nevertheless, the settlement data coincide with spat numbers used for re-seeding after thinning out of spat collectors for the grow-out phase in offshore cultures (Langan 2001). Finally, if the natural settlement of $\approx 800$ ind. $\mathrm{m}^{-1}$ at the longline site proves to be a reliable annual event, it can be suggested to eliminate the costly step of thinning and re-seeding the mussel spat. The growth rate determined at "Nordergründe" was approximately $5 \mathrm{~mm}$ per month, which denotes that grow-out from settlement to $\approx 30 \mathrm{~mm}$ can be achieved in 6 months. To cultivate mussels to market size $[<5 \mathrm{~cm}$ according to the Hagena (2002, personal communication), including a decline in growth rate during wintertime], a growth period of at least 12 months can be calculated. Thus, a full production cycle from spat settlement to market size can be reached within $12-15$ months.

Mytilus larvae in the water column and post-larvae settling on collectors were recorded. Ideally, grow-out locations for post-larvae are situated away from heavy spat settlement areas to avoid layers of spat attaching to larger mussels. At the location "Nordergründe" the spat fall is low compared to findings of Walter and Liebezeit (2001), thus preventing heavy overgrowth of free living post-larvae on newly suspended ropes with grow-out mussels.

\section{Environmental factors}

\section{Temperature}

While increasing growth of mussels ranges between 3 and $20^{\circ} \mathrm{C}$, a reduced growth above $20^{\circ} \mathrm{C}$ and below $3{ }^{\circ} \mathrm{C}$ was examined by Almade-Villela et al. (1982). They further determined that Mytilus edulis is well adapted to constantly changing environmental conditions, which is the case at "Nordergründe" in the Weser estuary, where temperature ranges annually from 1.8 to $22.4^{\circ} \mathrm{C}$ and tidally about $2.4^{\circ} \mathrm{C}$. The relatively warm waters at "Nordergründe", partly originating from the river Weser estuary and diluted with offshore waters (Fig. 4b), provide long-term mussel growing conditions and may enable aquaculturists to collect mussel spat as well as to grow mussels out to a marketable size within short time.

\section{Salinity}

When salinity falls below or above a certain value (15/ $50 \mathrm{ppt}$, Wilson and Seed 1974) for prolonged periods filtration rates decrease (Widdows and Donkin 1992; Gosling 2003). In worst cases, high mortalities within the cultivated mussels may occur (Almada-Villela 1984; Gruffydd et al. 1984). Decrease in salinity levels is usually the major and frequent problem, mainly caused by the influx of large volumes of fresh water from the river Weser or land runoff during the rainy season. Blue mussels may survive reduced salinity up to 4-5 ppt for a short time, however, those concentrations limit the mussel's growth rate and could lead to high mortalities (Kautsky et al. 1990). Such a drop in salinity will not occur in the Weser estuary at the location "Nordergründe", which range from 26.7 to 31.1 ppt.

\section{Maintenance, sampling and harvest}

The vessel used during this project, mainly the RV Uthörn, is too large to manoeuvre within the test area or to handle the longline system. Additionally, no special equipment normally used to lift longlines, to harvest mussels or to inspect the entire system were available. Thus, inflatable boats were used for maintenance works and sampling procedures. The longline, however, had to be lifted by hand to sample the collectors. The handling of the gear and the use of the smaller boats even at waves of "only" $2 \mathrm{~m}$ in height or within the short period during slack time made the offshore work difficult, even in some cases, weather conditions made the servicing and sampling procedure impossible.

The presence of fouling organisms is undesirable because they compete for food and space and critically increase the weight of each hanging unit. Generally, there is a need to remove these organisms (Bussani 1983). This laborious process, however, is not required in this particular site, as the increasing density of mussels over time take over space and force fouling organisms to detach or kill them by overgrowth. Further, total biomass of fouling can be reduced by deploying the longline and the collectors in early May prior to larval settlement to prevent the settlement of other organisms drifting in the water column in March to early May.

At "Nordergründe" the natural time from settlement to a size of $28 \mathrm{~mm}$ was measured to be approximately 6 months. At this time, one has to decide to grow mussels to market size or to supply the on-bottom culturists with spat. Only the latter technique requires a change of the set up. As already described above, it 
can be suggested to avoid this laborious procedure and follow an extensive way of mussel cultivation by leaving the settled mussels on the ropes until they reach market size. To follow the second possibility the culture season ends with seed harvest and mussels are planted on bottom culture plots in inshore areas. In this study, the mussels were harvested once when retrieving the entire longline and did not follow a grow-out period to determine, if suspended mussels do have thinner shells, which can lead to a shell damages.

The longline design: polypropylene versus steel hawser

The longline system design is probably the method that has been mostly used worldwide, especially for Mytilus cultivation (Polk 1996; Hesley 1997; Stickney 1998; Bridger and Costa-Pierce 2003). Similar to mussel rafts, the longline has been frequently modified over the course of time. In contrast to rafts operating in a floating mode on the water surface (Hickman 1992), making themselves unsuitable for high energy offshore environments, longlines can be deployed in a submerged mode at various depths to avoid some of these forces at near surface levels (Danioux et al. 1997). Such a flexible system was chosen for the German Bight and moored at the offshore lighthouse "Roter Sand" for long-term monitoring and testing.

These two longline systems were deployed in order to determine if offshore mussel growth at the location "Nordergründe" was feasible at a rate that it might become a form of offshore shellfish aquaculture. In comparison to other culture constructions, the longline system was chosen due to the easy deployment and the cheaper investment costs in comparison to other culture systems (Gosling 2003). Longlines can withstand relatively strong wind and wave action due to the flexibility of the system itself (Lovatelli 1988) and can resist harsh winters (Gosling 2003). Furthermore, growth rates of mussels are reported to be better using longline systems (Chaitanawisuti and Menasveta 1987; Hickman 1992). The only study where growth of mussels were investigated at three different culture designs, the pole, the on-bottom and the longline method, showed that the longline cultivated mussels demonstrated the best growth rates (Garen et al. 2004). This can be explained by the fact that longline mussels are fully suspended in the water and do only have a little hard substrate in the collector's centre and are therefore flushed by phytoplankton-rich seawater at all time.

Both, the polypropylene as well as the steel hawser longline, showed advantages while at the same time disadvantages. Maintenance work at both lines was complicated due to the submersed mode. Here, the polypropylene line with its surface floats eased the retrieving of the longline by lifting the floatation ropes to reach the harness. A lack of specific equipment, as it was described above, caused these problems and not the submerged design of the longline. On the contrary, the use of ball-like floats at the polypropylene line caused an increase in drag force, friction and tension on the entire system. Elongated fenders would protect the construction by better riding the swell to result in vertical movements, while the ball floats had resulted in jerking behaviour that created substantially more stress on all the materials and could further result in a loss of mussels by shaking them loose. However, it is necessary to reduce surface floatation as much as possible. Floats used in the submerged mode (steel hawser line) did not affect the longline greatly. But floats, which are attached to submerged parts of the longline should have in-compressible mantle, thus, no additional pressure due to water depth can limit the buoyancy.

Due to heavy weather conditions accomplished with strong currents and high wave action both systems were partly damaged. Tangling of the growing lines occurred and mussels were shaken off at times, when the longline was not submerged. While strands in the eye loops despite the inserted thimbles untwisted by the current and turbulences the longline could be retrieved easily. The segmentation of the steel hawser line showed advantages in the construction period and favoured the change of segments at sea stage. Unfortunately, the spliced wires with loops, to hold the collector on the bottom end and its buoyancy on the top end did not withstand the current. All wires were untwisted or broken and parts of the harness, such as collectors and floaters, lost. The replacement of the wires by metal plates resisted the current and wave actions and protected the harness from damage or loss.

Finally, we suggest eliminating the use of wire, which can result in chafing of polypropylene lines and will not be able to resist permanent movement due to currents and waves. Connection materials such as shackles, thimbles and swivels bring a lot of weight, which have to be absorbed by adding more floatation, increase investment costs and could also cause chafing of lines and collectors.

Site selection: Nordergründe

\section{Depth and aerial exposure}

Water depth is not usually a limiting factor in mussel culture, however, it will determine what culture method can be used and depth ranges between 1 and $15 \mathrm{~m}$, at some instances up to $50 \mathrm{~m}$ depth (Loste 2001; 
Langan personal communication) have been commonly reported as being useful. In areas where the mean tide level is usually less than $1.5 \mathrm{~m}$, on-bottom culture on the seafloor or on other materials (racks, bamboo sticks) can be practiced. Probably the most important aspect with regard to water depth in tidal seas is to avoid long exposure periods to air during the extreme low water spring tides. Long exposure time increase the culture period mainly due to the fact that the molluscs stop feeding and growth declines with aerial exposure duration (Yamada 1989) while also being exposed to rapid temperature changes (particularly during sunny days). For suspended culture methods, such as the deployed longlines, mussels feed continuously and therefore grow rapidly (Seed 1968a, b). Water depth can be a limiting factor in tidal seas as usually a minimum water column height is essential during the low water spring tides due to variations in food availability within the water column (Rodhouse et al. 1984; Page and Hubbard 1987). At the site Nordergründe, we suggest to submerge the longline at least 6-7 $\mathrm{m}$ to avoid the energy forces from waves. Sites with a depth of $>20 \mathrm{~m}$ would have a lesser impact on the longline system and would further allow longer collectors to guarantee economic return. Furthermore, the hanging harness should never touch the bottom mainly to prevent predators such as crabs and sea stars from reaching the bivalves, avoid exposing the mussels to high water turbidity near the seabed, and also avoid losing the mussels at the lower end of the collectors as a result of their friction with the ground. Therefore, a longline system was designed, which fits exactly to the location and its physical demands. The location "Nordergründe", where the longline design used in this study was deployed, has a water depth at low tide of about $12 \mathrm{~m}$. The collector harness suspended along the submerged longline in a depth of $5 \mathrm{~m}$ below the surface has a length of 2-3 m. Therefore the culture ropes are at all sea stages above the sea floor (at least $4 \mathrm{~m}$ ) also during extreme low water spring tides or at harsh weather conditions with wind waves of up to $6 \mathrm{~m}$.

\section{Food availability}

The annual chlorophyll concentrations indicate a distinct early phytoplankton spring bloom followed by lower summer values. There was a sufficient chlorophyll concentration in the surrounding water to sustain mussel growth (Sara et al. 1998). The determined seasonal availability of inorganic nutrients as an indicator for phytoplankton growth conditions became at no time limiting. The data are, even though at present not effectual for site selection criteria, sufficiently indica- tive to be used for correlations between phytoplankton density and composition, survival and settlement of larvae and growth of mussels.

\section{Currents and waves}

In the Wadden Sea current velocities of up to $1.5 \mathrm{~m} \mathrm{~s}^{-1}$ usually generate high turbidity and high siltation rates (Ehlers 1988; Brown et al. 1989). The presence of suspended materials above a certain level hinders the filtering activity of bivalves which often remain closed to avoid tissue damage and becoming clogged (Gosling 2003). Furthermore, finely suspended matter such as clay, sand, and other organic and inorganic particulate materials at the culture site is usually undesirable as it causes ill effects on the bivalves being cultured and often resulting in high mortalities (Lovatelli 1988). The collector harness of the deployed longline construction has enough clearance from the sea bottom to avoid sand uptake by the mussels and no further mussel cleaning from incorporated sand is necessary. Additionally, Secci-depth readings showed a low turbidity load within the test area (Buck, unpublished data) with values ranging from 3 to $8 \mathrm{~m}$ in summer time. Tiensongrusmee et al. (1986) have shown that water containing a high-suspended particle load of more than $400 \mathrm{mg} 1^{-1}$ have a lethal effect on the grow-out of mussels, thus sites having a disc reading less than $15 \mathrm{~cm}$ are usually considered unsuitable for bivalve culture.

However, moderate currents are needed to provide adequate transport of water masses carrying the food supply in form of phytoplankton. Slow water movement usually results in slow growth of the bivalves due to the poor replenishment of the food (Wildish and Kristmanson 1984, 1985; Jenkins 1985; Hickman 1989), however, mussels cultured within a high energy environment are not food-limited particularly in waters of high primary productivity (Klepper and van de Kamer 1988). Slow currents also promote the settling of organic and inorganic particulate materials on the cultured organisms (Lovatelli 1988). Indeed, clearance rates also decrease when current velocity exceeds a certain value due to the pressure differential between the inhalant and exhalent siphon (Gosling 2003). Potential sites for longline culture should have a current speed within the range of $0.02-1.5 \mathrm{~m} \mathrm{~s}^{-1}$ (Rosenberg and Loo 1983; Hickman et al. 1991). At "Nordergründe", measurements of current velocities at a depth of 4,6 and $8 \mathrm{~m}$ depth were $0.53 \pm 0.25$, $0.49 \pm 0.23$ and $0.44 \pm 0.21 \mathrm{~m} \mathrm{~s}^{-1}$, respectively (WSA 2002) to insure a minimum particle flow.

Exposure to high wave action normally disqualifies a potential cultivation site due to the loss of mussels 
through passive detachment (Scarratt 1993). Although waves of up to $6.4 \mathrm{~m}$ in height were determined, the choice of floatation and the depth of the suspended collector harness may offset the effect of extreme wave forces as it is the case for the dense living mussel spat at the deployed submerged longline system at "Nordergründe". Mortalities of mussels may occur if they are exposed to extreme wave action while at the same time food limited (Gosling 2003). The suspended cultivation method and the determined chlorophyll concentration as well as the POC/PON values eliminate these effects.

\section{Pollution}

Pollution of inshore areas and estuaries has been one of the most delicate subject for coastal countries in the past few years and has been a problem for decades in areas where mussel or oyster farming has been traditionally practiced (e.g., The Netherlands, Spain and France). The location of and the distances to the pollution sources relative to the selected offshore farm site should be carefully considered, particularly with regard to ongoing urban sewage release or diffuse coastal inputs from intensive agricultural activities. The coastal current patterns responsible for long-distance transport of potential pollutants should be carefully considered. Fortunately, the River Weser estuary and the adjacent offshore location at "Nordergründe" are monitored by the Bund Länder Messprogramm and various other local authorities, providing sufficient safeguard. Furthermore, mussels originating from wild habitats and culture plots are monitored routinely and are screened for toxins by local authorities (Zander, personal communication). There seems to be no need for further expansion of such costly monitoring activities for this location.

\section{Conclusion}

Site selection for an offshore aquaculture system is a process by which a number of factors need to be carefully analysed prior to the planning and technical installation thereby minimizing the risk of inappropriate investment. Despite the technical difficulties mentioned above, there seems to be suitable settlement densities and sufficiently fast growth at the test sites to employ a culture strategy for a complete growth cycle (from settlement to market size). It also seems to be fair to say that the data indicate a potential for mussel production in the offshore waters of the German Bight limited mainly by available space. The resulting knowledge of the project for design engineering and understanding operational logistics and management requirements is considered to be vital for the potential commercial development of a viable mussel offshore aquaculture industry.

The submersed deployment of a longline as harness for suspended mussel culturing eliminates the worst effects of surface waves and makes the system components robust and sustainable for a long time use. It is anticipated that material failures can be minimized by using polypropylene-based systems instead of stiff and inflexible wire-based systems or submerged elongated fender type installations. However, several serious scientific questions (e.g., long-term health status, fitness, spat fall), technological problems (e.g., connection to offshore constructions such as wind generators), and economic (e.g., economic returns, investment costs) as well as policy issues remain to be clarified or resolved before the potential of this form of aquaculture can be realized.

\section{Outlook}

The excellent growth rates of mussels during the present study led to the suggestion to build and install a number of longlines parallel to each other to prove the principal. This is considered to be an opportunity to conduct offshore mussel culture for a commercial enterprise by various ways: (1) to collect mussel spat to supply the on-bottom culturists in the tidal flats within the backwaters of the Frisian Island because of seed mussel shortages frequently occurring in subsequent years, (2) to collect the mussel spat and grow it to market size offshore, or (3) to use spat from inshore areas and use the offshore site as a grow-out location. For these purposes it is necessary to ascertain the consistency of seed settlement rates at a potential farm location. Also, while allowing settled seed to grow to market size on collector lines and therefore eliminating stripping and re-seeding to growing ropes, sizes could be inconsistent and yield of market mussels could be reduced and need to be verified.

Offshore cultivation of marine organisms is at the brink of becoming a new aquaculture production sector. Therefore, the development of a commercially viable offshore aquaculture operation on a pilot-scale basis seems to be a feasible undertaking once the testing is completed to reduce risks in all relevant technical and biological areas under concern. More specifically, future project activities should include R\&D elements targeted at reducing operational risks through a coordinated, interdisciplinary effort involving engineering research on offshore structures, analysis of scientific 
criteria concerning biological productivity, and studies on project economics. Finally, tests to assess the suitability (or comparability) of the resulting product at existing or new markets have to be done, while there is still a need to clarify the regulatory and licensing issues associated with offshore activities.

Although not harmful to the mussels themselves, growing areas may occasionally suffer from outbreaks of harmful toxic algae, which the mussels consume, rendering them unsuitable for human consumption. An algae-early warning system, which already exists for overall monitoring purposes but too wide-spread to serve the small-scale requirements of such a localized offshore industry should be expanded to areas used for offshore mussel culture.

In the past, because of the limited extent of areas used for aquaculture, such natural environmental events (e.g., algal blooms) have been dismissed as inconsequential. However, the proposed massive increase in areas to be used for mussel cultivation changes the scale of any impact and prompts concern. In particular, the construction of large (2,000-4,000 ha) mussel farms up to $7 \mathrm{~km}$ offshore will extend mussel cultivation into areas used by offshore species (petrels, shearwaters, seals and whales) that have not previously encountered mussel farms. The potential interactions with these species (e.g., disease transfer) will have to be tested.

Finally, once an offshore wind-farm is installed mussel culture constructions should be tested in a connected manner with the pylon of a wind farm. In this special case, it is of great importance that expensive offshore techniques, such as offshore windmills and offshore culture systems, do not develop independently.

Acknowledgments First of all I would like to thank Dr. Uwe Walter who helped sampling mussel larvae and spat and provided his knowledge to analyse data. Dipl. Biol. Matthias Brenner and Susanne Spahic supplied whatever was needed and supported the investigation by further practical help and good spirits. I would like to thank the Water and Shipping Agency in Bremerhaven for providing oceanographic data and by deploying and retrieving the entire longline harness. I gratefully acknowledge the dedicated help of the crew of the RV "Uthörn". Prof. Harald Rosenthal and Dr. Gesche Krause kindly advised and encouraged me at an early stage of the manuscript. Last, but not least, I wish to thank two anonymous reviewers who contributed their time and critical expertise helping to improve the manuscript.

\section{References}

Almade-Villela PC (1984) The effects of reduced salinity on the shell growth of small Mytilus edulis. J Mar Biol Assoc UK 64:171-182
Almade-Villela PC, Davenport J, Gruffydd LLD (1982) The effects of temperature on the shell growth of young Mytilus edulis L. J Exp Mar Biol Ecol 59:275-288

Becker G, Dick S, Dippner J (1992) Hydrography of the German Bight. Mar Ecol Prog Ser 91:9-18

von Bodungen B, Wunsch M, Fürderer H (1991) Sampling and analysis of suspended particles in the Northern North Atlantic. Geophys Monogr 63:47-56

Bos OG, Hendriks IE, Strasser M, Dolmer P, Kamermans P (2006) Food limitation of bivalve larvae in coastal waters of Northwestern Europe. J Sea Res 55:191-206

Bridger CJ, Costa-Pierce BA (2003) Open ocean aquaculture: from research to commercial reality. The World Aquaculture Society, Baton Rouge

Brown J, Colling A, Park D, Phillips J, Rothery D, Wright J (1989) Waves, tides and shallow water processes. Pergamon, Oxford

BSH (2002/2003) Bundesamt für Seeschifffahrt und Hydrographie (Federal Maritime and Hydrographic Agency). Wave measurements at several positions in the German Bight. Hamburg. Online data acquisition http://www.bsh.de

Buck BH (2002) Open ocean aquaculture und offshore-windparks: Eine Machbarkeitsstudie über die multifunktionale Nutzung von offshore-windparks und offshore-Marikultur im Raum Nordsee (open ocean aquaculture and offshore wind farms: a feasibility study on the multifunctional use of offshore wind farms and open ocean aquaculture in the North Sea). Reports on polar and marine research, Alfred Wegener Institute for Polar and Marine Research, Bremerhaven, No. 412

Buck BH (2004) Farming in a high energy environment: potentials and constraints of sustainable offshore aquaculture in the German Bight (North Sea). PhD thesis, University of Bremen, Germany

Buck BH, Buchholz CM (2004) The offshore-ring: a new system design for the open ocean aquaculture of macroalgae. J Appl Phycol 16:355-368

Buck BH, Buchholz CM (2005) Response of offshore cultivated Laminaria saccharina to hydrodynamic forcing in the North Sea. Aquaculture 250:674-691

Buck BH, Krause G, Rosenthal H (2004) Multifunctional use, environmental regulations and the prospect of offshore comanagement: potential for and constraints to extensive open ocean aquaculture development within wind farms in Germany. Ocean Coastal Manage 47:95-122

Buck BH, Berg-Pollack A, Assheuer J, Zielinski O, Kassen D (2006) Technical realization of extensive aquaculture constructions in offshore wind farms: consideration of the mechanical loads. In: Proceedings of the 25th international conference on offshore mechanics and arctic Engineering (OMAE 2006), offshore wind energy symposium, American Society of Mechanical Engineers (ASME), New York, pp 1-7

Bucklin A, Howell H (1998) Progress and prospects from the University of New Hampshire Open Ocean Aquaculture Demonstration Project. In: Stickney RR (ed) Joining forces with industry-open ocean aquaculture. Proceedings of the third annual international conference. TAMU-SG-99-103, Texas Sea Grant College Program, Corpus Christi, pp 7-30, 10-15 May

Bussani M (1983) Guida pratica di miticultura. Edagricole

Cáceres-Martínez J, Figueras A (1998) Distribution and abundance of mussel (Mytilus galloprovincialis LMK) larvae and post-larvae in the Ria de Vigo (NW Spain). J Exp Mar Biol Ecol. 229:277-287

Chaitanawisuti N, Menasveta P (1987) Experimental suspended culture of green mussel, Perna viridis (Linn.), using spat 
transplanted from a distant settlement ground in Thailand. Aquaculture 66:97-107

CWSS (2002) Shellfish fisheries. An overview of policies for shellfish fishing in the Wadden Sea. Common Wadden Sea Secretariat, Wilhelmshaven (Germany)

Dahle LA, DePauw N, Joyce J (1991) Offshore aquaculture technology—possibilities and limitations. Aquac Environ 14:8384

Danioux C, Loste C, Paquotte P (1997) Offshore mollusc production in the Mediterranean basin. In: Muir J, Basurco B (eds) Options méditerranéennes-Mediterranean offshore mariculture. Etudes et recherches, Serie B, Numéro 30, Zaragoza, CIHEAM, INO Reproducciones, pp 115-140

Dobretsov SV, Miron G (2001) Larval and post-larval vertical distribution of the mussel Mytilus edulis in the White Sea. Mar Ecol Prog Ser 218:179-187

Dolmer P (1998) Seasonal and spatial variabiblity in growth of Mytilus edulis L. in a brackish sound: comparisons of individual mussel growth and growth of size classes. Fish Res 34:1726

Ducrotoy JP, Elliott M, De Jonge VN (2000) The North Sea. Mar Pollut Bull 41:5-23

Ehlers J (1988) The morphodynamics of the Wadden Sea. Balkema, Rotterdam

Ewaldsen P (2003) Erzeugerorganisation schleswig-holsteinischer Muschelzüchter e.V. (Head of the Organisation of Shellfish Producer in S.-H.). Protocol of the 1st session of the expert meeting dealing with fisheries, offshore wind farms and open ocean aquaculture. Emmelsbüll-Horsbüll (Germany), 19 March 2003

FAO (2004) FAO-Fisheries Department, Fishery Information, Data and Statistics Unit. FISHSTAT Plus. Universal Software for fishery statistical time series. Food and Agriculture Organisation of the United Nations, Rome (Italy). Version 2.3. last updated March 2004

Gabbott PA (1975) Storage cycles in marine bivalve molluscs: a hypothesis concerning the relationship between glycogen metabolism and gametogenesis. In: Proceedings of the 9th European marine biology symposium. Scotland Aberdeen University Press, Aberdeen, pp 191-211

Garen P, Robert S, Bougrier S (2004) Comparison of growth of mussels, Mytilus edulis, on longline, pole and bottom culture sites in the Pertuis Breton, France. Aquaculture 232:511-524

Gosling E (2003) Bivalve molluscs: biology, ecology and culture. Blackwell Publishing, MPG Books, Bodmin

Gruffydd LLD, Huxley R, Crisp DJ (1984) The reduction in growth of Mytilus edulis in fluctuating salinity regimes measured using laser diffraction patterns and the exaggeration of this effect by using tab water as the diluting medium. J Mar Biol Assoc UK 64:401-409

Hagena W (2002) Fisheries statistics of the state fishery authority. Bremerhaven, Germany

Hamilton (1997) Community consequences of habitat use and predation by common Eiders in the intertidal zone of Passamaquoddy Bay. PhD thesis, University of Guelph, Ontario

Hamilton DJ, Nudds TD, Neate J (1999) Size-selective predation of Blue Mussels (Mytilus edulis) by Common Eiders (Somateria mollissima) under controlled field conditions. Auk 116:403-416

Heiber W (1988) Die Faunengemeinschaft einer großen Stromrinne des Wurster Wattengebietes (Deutsche Bucht). PhD thesis, University of Bonn, Germany

Hesley C (1997) Open ocean aquaculture: chartering the future of ocean farming. In: Proceedings of an international conference. UNIHI-Seagrant-CP-98-08, University of Hawaii Sea Grant College Program, Maui, 23-25, April 1997
Hickman RW (1989) Farming the green mussel in New Zealand. Current practise and potential. World Aquac 20:20 28

Hickman RW (1992) Mussel Cultivation. In: Gosling E (ed) The mussel Mytilus: ecology, physiology, genetics and culture. Development in aquaculture and fisheries science no. 25. Elsevier, Amsterdam, pp 465-510

Hickman RW, Waite RP, Illingworth J, Meredyth-Young JL, Payne G (1991) Relationship between farmed mussels Perna canaliculus and available food in Pelorus-Kenepuru Sound, New Zealand, 1983-1985. Aquaculture 99:49-68

Jenkins RJ (1985) Mussel cultivation in the Marlborough sounds (New Zealand), 2nd revised edn. Fishing Industry Board, NZ

Kautsky N (1982) Growth and size structure in a Baltic Mytilus edulis population. Mar Biol 68:117-133

Kautsky N, Johannesson J, Tedengren M (1990) Genotypic and phenotypic differences between Baltic and North Sea populations of Mytilus edulis evaluated through reciprocal transplantations. 1. Growth and morphology. Mar Ecol Prog Ser 59:203-210

Klepper O, Van de Kamer JPG (1988) A definition of the consistency of the carbon budget of an ecosystem, and its application to the Oosterschelde-Estuary, SW Netherlands. Ecol Modell 42:217-232

Kraul T (1994) Gelöste und partikuläre Stickstoff- und Phosphorverbindungen in der Nordsee. Diploma thesis, University of Oldenburg, Germany

Krause G, Buck BH, Rosenthal H (2003) Multifunctional use and environmental regulations: potentials in the offshore aquaculture development in Germany, rights and duties in the coastal zone, multidisciplinary scientific conference on sustainable coastal zone management, Stockholm (Sweden), 12-14 June 2003

Kristensen PS, Lassen H (1997) The production of relaid blue mussels (Mytilus edulis L.) in a Danish fjord. ICES J Mar Sci $54: 854-865$

Lande E (1973) Growth, spawning and mortality of the mussel (Mytilus edulis L.) in Prestvaagen, Trondheimsfjorden. K Nor Vidensk Selsk Mus Misc 11:1-26

Langan R (2001) Advances in submerged longline culture of blue mussels Mytilis edulis in the open ocean. In: Bridger CJ, Reid $\mathrm{TH}$ (eds) Open ocean aquaculture IV, symposium program and book of abstracts. Mississippi-Alabama Sea Grant Consortium, Ocean Springs, MS MASGP-01-006, St Andrews, pp 73-74, 17-20 June 2001

Langan R, Horton F (2003) Design, operation and economics of submerged longline mussel culture in the open ocean. Bull Aquac Assoc Can 103:11-20

Leonard GH, Bertness MD, Yund PO (1999) Crab predation, waterborne cues, and inducible defenses in the blue mussel, Mytilus edulis. Ecology 80:1-14

Loste C (2001) Other offshore systems: mollusc production. advanced course on Mediterranean offshore mariculture, Centro Internacional de Altos Estudios Agronomico Mediterraneos (CIHAEM); Institutio Agronomico Mediterraneo de Zaragoza (IAMZ), Food and Agriculture Organisation (FAO), Zaragoza

Lovatelli A (1988) Site selection for mollusc culture. Workshop on GIS applications in aquaculture held at AIT, Bangkok, 5-23 December 1988

Menzel W (ed) (1991) Estuarine and marine bivalve mollusk culture. CRC, Boca Raton

Metaxas A (2001) Behaviour in flow: perspectives on the distribution and dispersion of meroplanktonic larvae in the water column. Can J Fish Aquat Sci 58:86-98 
NLÖ (2003) Bund/Länder-Messprogramm für die Meeresumwelt von Nord- und Ostsee. Niedersächsisches Landesamt für Ökologie

Page HM, Hubbard DM (1987) Temporal and spatial patterns of growth in mussels Mytilus edulis on an offshore platform: relationships of water temperature and food availability. J Exp Mar Biol Ecol 111:159-179

Polk M (1996) Open ocean aquaculture. In: Proceedings of an international conference, Portland, Maine. UNHMP-CPSG-96-9, Portland, New Hampshire/Maine Sea Grant College Program, 8-10 May 1996

Pulfrich A (1995) Reproduction and recruitment in SchleswigHolstein Wadden Sea edible mussel (Mytilus edulis L.) populations. PhD thesis, University of Kiel, Germany

Pulfrich (1997) Seasonal variation in the occurrence of planktic bivalve larvae in the Schleswig-Holstein Wadden Sea. Helgol Wiss Meeresunters 51:23-39

Reusch TBH, Chapman ARO (1997) Persistence and space occupancy by subtidal blue mussel patches. Ecol Monogr 67:6587

Rodhouse PG, Roden CM, Burnell GM, Hensey MP, McMahon T, Ottway B, Ryan TH (1984) Food resource, gametogenesis, and growth of Mytilus edulis on the shore and in suspended culture: Killary Harbour, Ireland. J Mar Biol Assoc UK 64:513-529

Rosenberg R, Loo LO (1983) Energy-flow in a Mytilus edulis culture in western Sweden. Aquaculture 35:151-161

Ryan J (2005) Offshore aquaculture-do we need it, and why is it taking so long? International Salmon Farmers Association (Ireland). Expert workshop on "Sustainable Aquaculture", DG JRC European Commission, Institute for Prospective Technological Studies, Seville (Spain), 17-18th January 2005

Sara G, Manganaro A, Cortese G, Pusceddu A, Mazzola A (1998) The relationship between food availability and growth in Mytilus galloprovincialis in the open sea (southern Mediterranean). Aquaculture 167:1-15

Scarratt D (1993) A handbook of Northern mussel culture. Island Press, Montague, pp 167

Seaman MNL, Ruth M (1997) The molluscan fisheries of Germany. NOAA Tech Rep NMFS 129:57-84

Seed R (1968a) Factors influencing shell shape in the mussel Mytilus edulis. J Mar Biol Assoc UK 48:561-584

Seed R (1968b) Factors influencing shell shape in the mussel Mytilus edulis. J Mar Biol Assoc UK 48:561-584

Seed R, Suchanek TH (1992) Population and community ecology of Mytilus. In: Gosling E (ed) The mussel Mytilus: ecology, physiology, genetics and culture. Development in aquaculture and fisheries science no. 25. Elsevier, Amsterdam, pp 87-169

Stickney RR (1998) Joining forces with industry-open ocean aquaculture. In: Proceedings of the third annual international conference. TAMU-SG-99-103, Corpus Christi, Texas Sea Grant College Program, 10-15 May

Tiensongrusmee B, Pontjoprawiro S, Soedjarwo I (1986) Site selection for the culture of molluscs. FAO/UNDP, INS/81/ 008/Manual/3

Tortell P (1976) A new rope for mussel farming. Aquaculture 8:383-388

de Vooys CGN (1999) Numbers of larvae and primary plantigrades of the mussel Mytilus edulis in the western Dutch Wadden Sea. J Sea Res 41:189-201

Walter U, Liebezeit G (2001) Nachhaltige Miesmuschel-Anzucht im niedersächsischen Wattenmeer durch die Besiedlung natürlicher und künstlicher Substrate. Abschlußbericht des ersten Projektjahres

Walter U, Buck BH, Liebezeit G (2006) Larval occurrence and settlement in the German Bight: a trial to estimate potentials for Mytilus edulis culture in offshore areas, Aquaculture International (submitted)

Widdows J, Donkin P (1992) Mussels and environmental contaminants: bioaccumulation and physiological aspects. In: Gosling E (ed) The mussel Mytilus: ecology, physiology, genetics and culture. Development in aquaculture and fisheries science no. 25. Elsevier, Amsterdam, pp 383-424

Wildish DJ, Kristmanson DD (1984) Importance to mussels of the benthic boundary layer. Can J Fish Aquat Sci 41:16181625

Wildish DJ, Kristmanson DD (1985) Control of suspension feeding bivalve production by current speed. Helgol Meeresunters 39:237-243

Wilson JH, Seed R (1974) Laboratory experiments in pumping and filtration in Mytilus edulis L. using suspensions of colloidal graphite. Ir Fish Invest Series B 14:1-20

WSA (2002) Water and Shipping Authority Bremerhaven. Yearly measurements of current velocities, temperature and salinities at the surface and in 3, 6,9 and $12 \mathrm{~m}$ depth. Bremerhaven, Germany

Yamada SB (1989) Mytilus californianus, a new aquaculture species. Aquaculture 81:275-284

Young EF, Bigg GR, Grant A, Walker P, Brown J (1998) A modelling study of environmental influences on bivalve settlement in the Wash, England. Mar Ecol Prog Ser 172:197-214 